\title{
Effect of Different Concentrations of Forskolin Along with Mature Granulosa Cell Co-Culturing on Mouse Embryonic Stem Cell Differentiation into Germ-Like Cells
}

\author{
Soghra Bahmanpour, Amirhesam Keshavarz and Nehleh Zarei Fard* \\ Laboratory for Stem Cell Research, Department of Anatomical Sciences, School \\ of Medicine, Shiraz University of Medical Sciences, Shiraz, Iran
}

Received 29 September 2018; accepted 23 December 2018; published online 28 August 2019

\begin{abstract}
Background: Germ cell development processes are influenced by soluble factors and intercellular signaling events between them and the neighboring somatic cells. More insight into the molecular biology of the germ cell development from ES cells and investigation of appropriate factors, specifically those targeting differentiation processes, is of great importance. In this study, we established an in vitro model with higher ES cell differentiation rate to germ cells, using adenylate cyclase activator, forskolin. Methods: ES cells were first cultured for five days, leading to EB formation. Subsequently, the EBs were dissociated and cultured for an additional three days in different forskolin concentrations of 5,20 , and $50 \mu \mathrm{M}$, with or without GC co-culture. On the $8^{\text {th }}$ day, we analyzed the expressions of 5 germ cell-specific markers using quantitative real-time-PCR technique along with cell viability assay by MTT test. Results: Our results showed that in the GC-free cultures, a $50-\mu \mathrm{M}$ concentration of forskolin resulted in a significant increase in $M v h, G d f 9, S c p 3$, and Rec8 expression levels in comparison to the control. However, when the cells were co-cultured with the GCs, 20- $\mu \mathrm{M}$ concentration of forskolin could also increase the expression of those germ cell-specific marker genes. Furthermore, results from the MTT assay showed enhanced cell proliferation and survival at all three concentrations of forskolin, but 20- $\mu \mathrm{M}$ concentration was the most potent one. Conclusion: These data indicate that forskolin can stimulate differentiation and proliferation, dose-dependently; however, the influence of GCs co-culturing should not go unnoticed. DOI: 10.29252/ibj.24.1.30
\end{abstract}

Keywords: Embryonic stem cells, Forskolin, Germ cells, Granulosa cells

Corresponding Authors: Nehleh Zareifard

Laboratory for Stem Cell Research, Department of Anatomical Sciences, School of Medicine, Shiraz University of Medical Sciences, Shiraz, Iran;

Tel.: (+98-711) 2304372; Fax: (+98-711) 2304372; E-mail: zareifard@sums.ac.ir

\section{INTRODUCTION}

$\mathrm{A}$ $\mathrm{n}$ interesting area of germ cell biology is to understand the molecular mechanisms of germ cell specification and development. In this sense, an extensive research should be carried out to identify suitable factors that specifically trigger germ cell differentiation process. One strategy to study gametogenesis is by inducing germ cell differentiation from the ES cells in vitro.

Several studies have reported the expression of germ cell-specific genes in ES cells using various factors, such as RA, bone morphogenetic protein 4 , and basic fibroblast growth factor ${ }^{[1-3]}$. The positive effects of ES cell co-cultivation with GCs or other somatic cells have also been investigated ${ }^{[2,-7]}$. Recently, it has been reported that the combinatorial application of $10 \mu \mathrm{m}$ forskolin and rolipram, which both increase the cAMP levels, can stimulate the proliferation and development of the primordial germ cell-like cells derived from the mouse ES cells ${ }^{[8]}$.

It has been postulated that adenylate cyclase 
activation by the non-physiological activator forskolin is accountable for synthesis of the second messenger cAMP. The adenylate cyclase-cAMP system can induce various biological and biochemical effects on different cells, depending on the cell type and the applied concentration ${ }^{[9]}$. In this regard, the role of cAMP in initiating meiosis in germ cells, regulation of oocyte maturation, and cell proliferation has been documented $^{[10-15]}$. On the other hand, researches have shown that increased cAMP levels in the denuded oocytes and cumulus cell-enclosed oocytes in response to forskolin exposure can induce or block meiosis via different pathways ${ }^{[16-18]}$. Although the role of forskolin has been recognized in the development of germ cells from ES cells ${ }^{[8]}$, there has been no investigation on the suitable dose of forskolin to induce germ cell differentiation from ES cells. The processes of in vitro ES cells differentiation to germ cell-like cells might be different from primordial germ cells development within fetal gonads.

As a priority, it is important to identify the suitable dose of exogenous factors inducing germ cell differentiation from ES cells with higher frequency. In this study, the effects of three different concentrations of forskolin on germ cell differentiation were investigated. In addition, we designed two approaches of induction of germ cell differentiation including with or without co-culturing the cells with GCs, and then the germ cell markers were examined to determine the rate of germ cell differentiation in each method.

\section{MATERIALS AND METHODS}

\section{ES culture}

Undifferentiated mouse ES cell line $\mathrm{R} 1^{[19]}$ was cultured on inactivated mouse embryonic fibroblasts in KnockOut D-MEM medium (Gibco, UK) supplemented with $15 \%$ ES cell-qualified FBS, $1 \%$ penicillin/streptomycin, $2 \mathrm{mM}$ of L-glutamine, $0.1 \mathrm{mM}$ of non-essential amino acids (all from Gibco), $0.1 \mathrm{mM}$ of $\beta$-mercaptoethanol (Sigma, UK), and $1000 \mathrm{U} / \mathrm{mL}$ of leukemia inhibitory factor (Chemicon, USA) and incubated in a humidified atmosphere containing 5\% $\mathrm{CO}_{2}$ at $37{ }^{\circ} \mathrm{C}$. Half of the medium was changed daily, and the cells were passaged every two days.

\section{GC culture}

Ovarian GCs were obtained from the ovaries of adult $\mathrm{BALB} / \mathrm{c}$ mice based on the method provided by Sèdes ${ }^{[20]}$, with minor modifications. Briefly, following the collection of ovaries from adult mice, trimming was done to omit extra tissues $48 \mathrm{~h}$ after gonadotropin administration. First, the ovaries were exposed to 6.8 $\mathrm{mM}$ of EGTA and $0.2 \% \mathrm{BSA}$ in the DMEM/F12 medium (Shelmax, Iran) at $37{ }^{\circ} \mathrm{C}$ for $20 \mathrm{~min}$. Then the ovaries were placed in a hypertonic solution $(0.5 \mathrm{M}$ of sucrose, $1.8 \mathrm{mM}$ of EGTA and $0.2 \% \mathrm{BSA}$ ) in DMEM/F12 at $4{ }^{\circ} \mathrm{C}$ for $5 \mathrm{~min}$. After that, the ovaries were punctured with an insulin needle, and the cells were pelleted by a 5-min centrifugation at $1200 \mathrm{rpm}$. The collected cells were seeded in DMEM/F12 with $10 \%$ FBS and $1 \%$ penicillin/streptomycin and maintained in a $5 \% \mathrm{CO}_{2}$ incubator at $37{ }^{\circ} \mathrm{C}$ overnight. The remaining oocytes were then separated from the attached GCs through GC subculture. GCs were used as a feeder layer at the second passage in 24-well culture plates pre-coated with $0.1 \%$ gelatin at a density of $5 \times 10^{4}$ cells/well (Jet Biofil, Korea), after inhibiting the proliferation by incubating with $10 \mu \mathrm{g} / \mathrm{mL}$ of mitomycin $\mathrm{C}$.

\section{ES cell differentiation}

ES cells were isolated from the feeder layer by the incubation of single cell suspensions on gelatin-coated tissue culture plates at $37{ }^{\circ} \mathrm{C}$ for $1-1: 30 \mathrm{~h}$ and differentiated as EBs through hanging drop method. For hanging drop culture, the isolated ES cells were seeded in leukemia inhibitory factor-free ES medium at a density of 2000 cells $/ 20 \mu \mathrm{L}$ for 2 days. Thereafter, the cells were collected and transferred into nonadhesive plates and cultured until the $5^{\text {th }}$ day. After EBs formation, EBs-derived differentiation cells were dissociated and cultured at a density of $5 \times 10^{4}$ or $10^{5}$ cells/well (24-well culture plate), with or without GCderived feeder cells, respectively. The germ cell differentiation media were DMEM/F12 supplemented with $10 \%$ FBS, $2 \mathrm{mM}$ of L-glutamine, $0.1 \mathrm{mM}$ of $\beta$ mercaptoethanol, and $0.1 \mathrm{mM}$ of non-essential amino acids with $5 \mu \mathrm{M}, 20 \mu \mathrm{M}$, or $50 \mu \mathrm{M}$ concentrations of forskolin (Sigma) as the experimental groups or without treatment as the control group (Fig. 1). The cells were cultured in these media for three more days, and half of the differentiation media were changed on day two. Morphological modifications were monitored daily by an invert microscope (Olympus, UK) equipped with a Nikon DXM-1200C digital camera. All analyses were performed on day eight of ES cell differentiation protocols. To be sure about the probability of germ cell expression markers by GCs, these cells were seeded in the same media alone for gene expression assessment.

\section{Quantitative real-time -PCR analysis}

Total RNAs were isolated from the experimental groups, using the Biazole reagent (Bioflux, Japan). Genomic DNA contamination was eliminated by DNase I, and cDNA was prepared in a total volume of $20 \mu \mathrm{L}$ via the cDNA synthesis kit (Fermentase, 


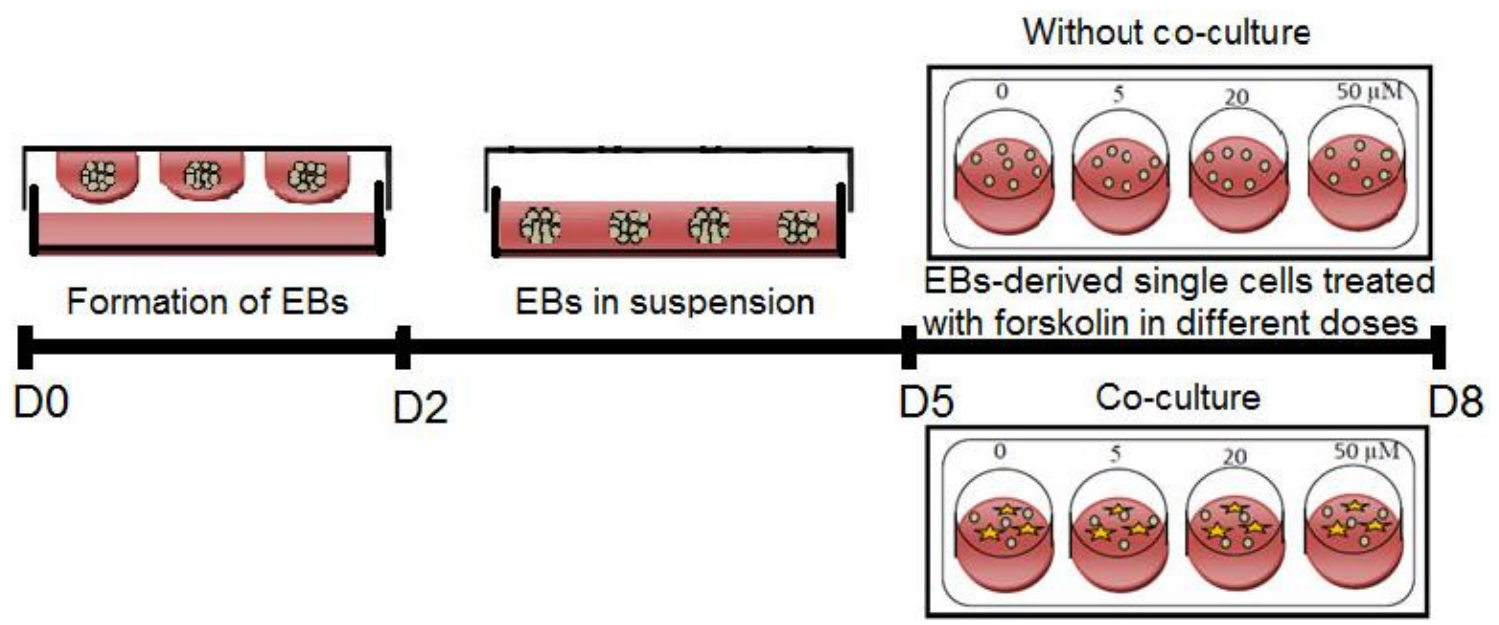

Fig. 1. Schematic presentation of the experimental protocol used for the ES cell-derived germ-like cells by treatment of cells at different concentrations of forskolin in the presence or absence of granulose feeder layer.

Lithuania), based on the manufacturer's instructions. Expression and quantity of Stra8, Scp3, Rec8, Mvh, and $G d f 9$ genes were assessed using the SYBR Green I PCR Master Mix (Applied Biosystems, USA) containing $150 \mathrm{nmol}$ of each forward and reverse primer (Table 1). The annealing temperature was $57{ }^{\circ} \mathrm{C}$, and the running cycles were 40 on an Applied Biosystems 7500 System. Target gene expression was normalized by the housekeeping gene $\beta$-actin.

\section{MTT assay}

Viability of germ-like cells differentiated from ES cells in the presence of various forskolin concentrations in the no co-culture group was analyzed via MTT (Sigma, UK) assay. Accordingly, cells were incubated with $500 \mu \mathrm{L}$ of $5 \mathrm{mg} / \mathrm{mL}$ MTT for $4 \mathrm{~h}$, followed by an elution of the dye with $200 \mu \mathrm{L}$ of DMSO (Sigma, USA). Thereafter, the cells were transferred into a 96-well plate, and their absorbance rate was measured at a $595 \mathrm{~nm}$ wavelength, using a microplate reader (BioPhotometer plus Eppendorf, Germany).

\section{Statistical analysis}

Results were presented as mean \pm SD. Statistical analyses were performed using One-way ANOVA, and the post-hoc test of LSD in SPSS 22.0 for windows (SPSS, Chicago, USA), and the graphs were plotted via the Prism v6.07 software (GraphPad software, USA). A $p$ value $<0.05$ was regarded to be statistically significant.

\section{Ethical statement}

The above-mentioned sampling protocols were approved by the Research Ethics Committee of Shiraz University of Medical Sciences, Shiraz, Iran.

\section{RESULTS}

We examined the expression of germ cell markers by exposing ES cells to different concentrations of forskolin in the presence/absence of GCs, aiming to determine whether forskolin is involved in the regulation of germ cell differentiation from ES cells. We assessed the possibility for expression of germ cell markers by GCs, used for co-culture groups, by the evaluation of mRNA levels, and the result showed negligible expression levels of these markers.

We found that in the absence of GCs, Mvh expression, as a germ cell-specific gene, significantly enhanced by adding $50 \mu \mathrm{M}$ of forskolin in comparison

Table 1. The sequences of specific primers used in this study

\begin{tabular}{cll}
\hline Gene & Forward primer $\left(\mathbf{5}^{\prime} \mathbf{- 3}\right)$ & Reverse $\mathbf{p r i m e r}(\mathbf{5} \mathbf{\prime}-\mathbf{3})$ \\
\hline Stras & GCATGAAGGACAGCGGCGTG & AAAGGATCTCTTCTGGGGTGGACTC \\
$S c p 3$ & GCAGAGAGCTTGGTCGGGGC & CTTTAGATGTTTGCTCAGCGGCTCC \\
$\operatorname{Rec} 8$ & GCCCTAGAAGGTGCTGGTTTGG & GTGGGGTCACCTCAGTGAGTAGG \\
$M v h$ & CAAGCGAGGTGGCTGCCAAG & CTGAATCACTTGCTGCTGGTTTCC \\
Gdf9 & CGTCCGGCTCTTCAGTCCCT & CCATCGGCAGCGGTCCTGTC \\
$\beta$-actin & CCCGCGAGCACAGCTTCTTTG & CCATCACACCCTGGTGCCTAGG \\
\hline
\end{tabular}


with the control condition. The concentration of $5 \mu \mathrm{M}$ of forskolin increased $M v h$ expression in EB-derived differentiated cells, but it was not significant compared with the control $(p=0.069)$. Also, a significant increase in $M v h$ expression was observed in both high concentrations of forskolin $(20$ and $50 \mu \mathrm{M})$, using the co-culture method ( $p=0.03$ and $p=0.004$, Fig. 2A).

The expression level of Gdf9, as a post-meiotic marker, significantly elevated at $50 \mu \mathrm{M}$ concentration of forskolin in the absence of granulosa feeder layer $(p$ $=0.006$ ). Furthermore, there was a significant reduction in $G d f 9$ expression at 5 and $20 \mu \mathrm{M}$ forskolin concentrations compared with those in the control cultures ( $p=0.0001, p=0.0004$, respectively). It should be noted that when EB-derived differentiated cells were co-cultured with the GCs, Gdf9 expression was slightly, but not significantly higher at 20 and 50 $\mu \mathrm{M}$ forskolin concentrations than the control group ( $p$ $=0.7, p=0.2$, respectively, Fig. 2B).

In the absence of GCs, the expression of pre-meiotic gene Stra 8 increased significantly compared with the control group in concentration of $5 \mu \mathrm{M}(p=0.0001)$. In contrast, in the co-culturing groups, its expression significantly reduced at 5 and $20 \mu \mathrm{M}$ concentrations ( $p$ $=0.00005, p=0.02$, respectively) and was not affected by $50 \mu \mathrm{M}$ of forskolin $(p=0.2$, Fig. $3 \mathrm{~A})$. Moreover, without co-culturing the cells with GCs, the expression of meiotic genes $S c p 3$ and $\operatorname{Rec} 8$ significantly elevated at the $50 \mu \mathrm{M}$ concentration of forskolin $(p=0.003$ and $p=0.01$, respectively). Interestingly, when the coculture method was applied, $S c p 3$ expression increased significantly at both 20 and $50 \mu \mathrm{M}$ concentrations in comparison to the control ( $p=0.00001$ and $p=0.036$, respectively). Meanwhile, similar results were obtained in Rec 8 expression at 20 and $50 \mu \mathrm{M}$ concentrations ( $p$ $=0.001$ and $p=0.003$, respectively, Fig. 3B and 3C).

In addition, the morphological observations revealed that both culturing methods had led to cell proliferation and formed colonies with similar morphology to those in ES cells (Fig. 4A and 4B). However, after day two, the round cells appeared only around the colonies in all experimental groups at approximately the same cellular density in the co-culture method, which were considered as germ-like cells in the size range of 10-15 $\mu \mathrm{M}$. In contrast, no round cells were observed in cultures without the granulosa feeder layer, and the colonies were less attached to the culture plates in this method that were surrounded by flat-expanded cells (Fig. 4C and 4D).
Without co-culture
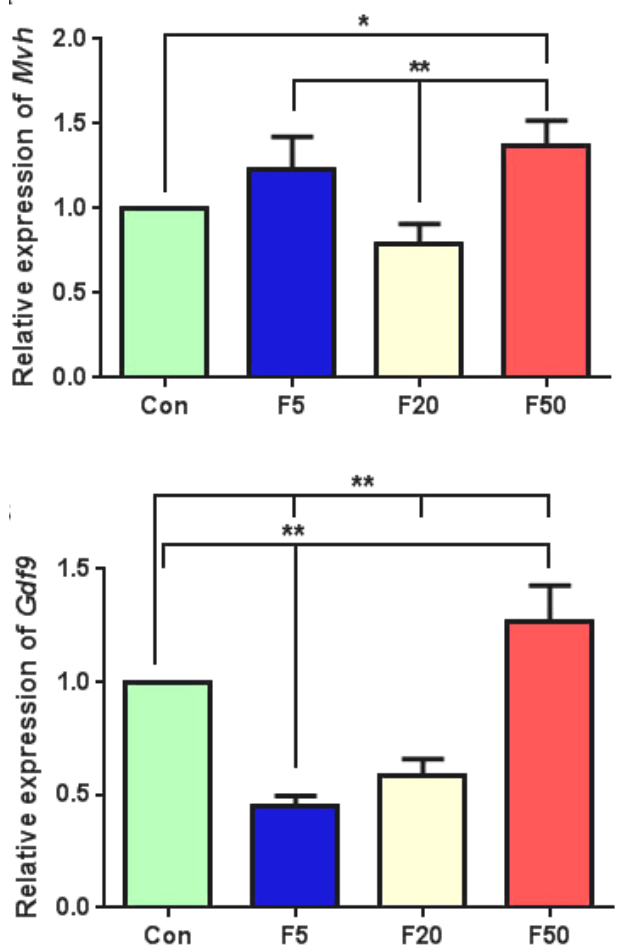

(A)

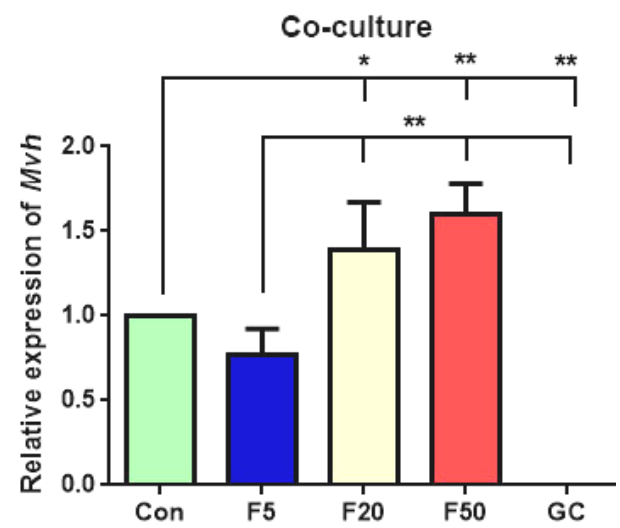

(B)

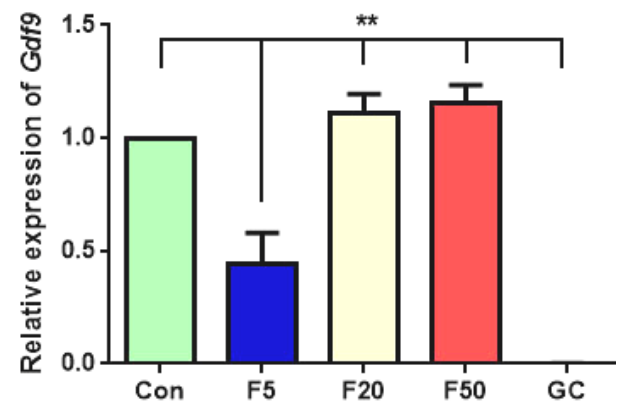

Fig. 2. QRT-PCR analysis of (A) $M v h$ and (B) Gdf9 expression in differentiated cells after treatment with different forskolin (F) concentrations $(5 \mu \mathrm{M}, 20 \mu \mathrm{M}$, and $50 \mu \mathrm{M})$, with or without $\mathrm{GC}$ co-culture. The gene expression was also analyzed for GC cultures alone. The results were presented relative to control RNA level. Data are presented as means $\pm \mathrm{SD}(\mathrm{n}=3) .{ }^{*} p<0.05,{ }^{* * *} p<0.01$; Con, control 
Without co-culture

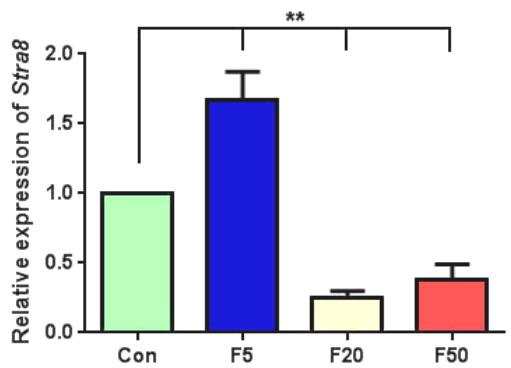

(B)

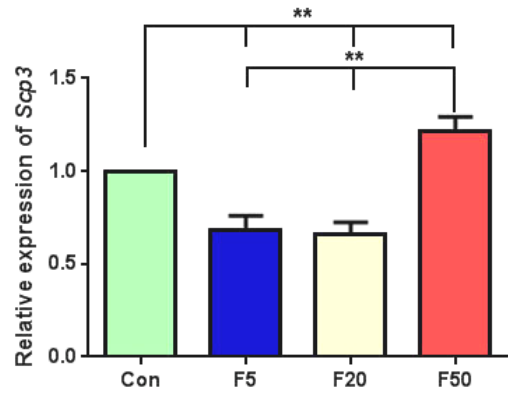

(C)

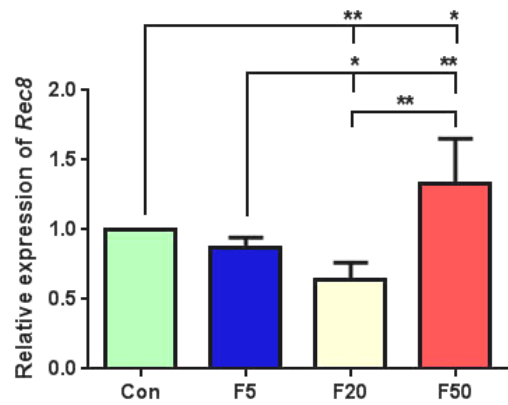

(A)
Co-culture
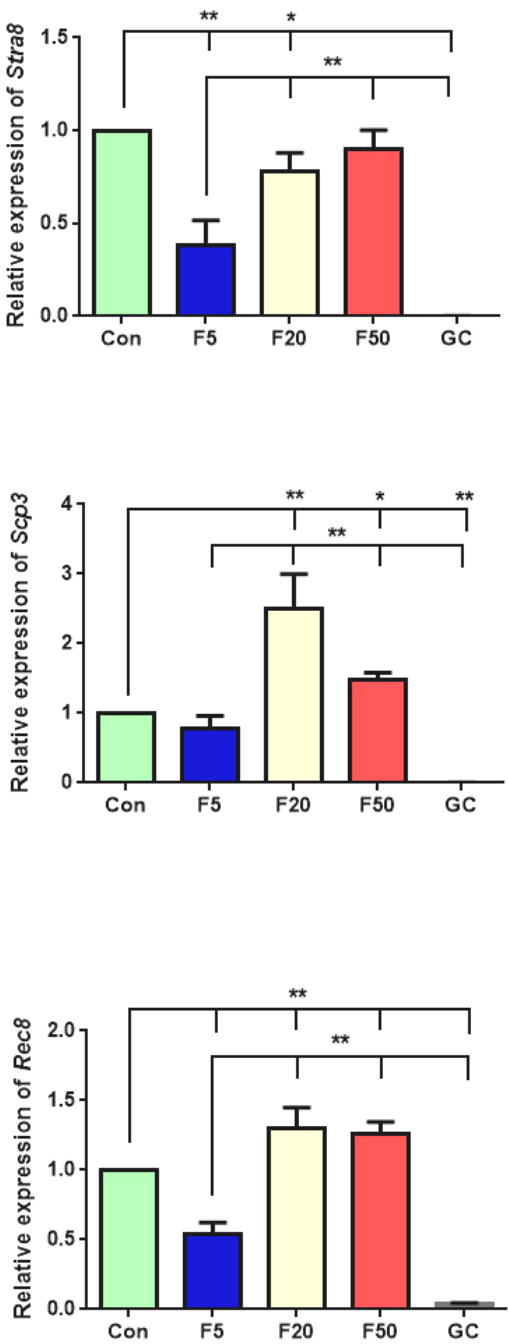

Fig. 3. Gene expression analysis of meiotic markers, including (A) Stra8, (B) $S c p 3$, (C) Rec8 in differentiated cells after treatment with three different forskolin $(\mathrm{F})$ concentrations $(5,20$, and $50 \mu \mathrm{M})$, with or without GC co-culture. GCs were cultured alone for controlling these gene expression patterns. Values are means $\pm \mathrm{SD}(\mathrm{n}=3) .{ }^{*} p<0.05,{ }^{* *} p<0.01$; Con, control

Cell viability was shown via MTT assay. The results reveled that forskolin significantly induced higher cell proliferation in all concentrations in comparison to the same cells cultured in the absence of forskolin $(p<$ $0.001)$, while $20 \mu \mathrm{M}$ concentration was more effective $(p=0.00001$, Fig. 4E).

\section{DISCUSSION}

Exploring the molecular mechanism of germ cell development is crucial for both basic and clinical research. In the present study, we showed that forskolin can dose-dependently regulate germ cell differentiation from ES cells. Aforementioned data indicates the presence of forskolin-stimulated $M v h$ and $G d f 9$ expressions, which was dose dependent. $M v h$ expression is considered as the germ cell-specific marker, and $G d f 9$ plays a critical role in folliculogenesis ${ }^{[21,22]}$. Inducing cAMP signaling has been found. To induce early gametogenesis and oocyte development ${ }^{[12,14,15]}$. According to our findings, high concentration of forskolin $(50 \mu \mathrm{M})$ can be considered alone as another factor influencing germ cell differentiation from ES cells. In addition, the current study showed increased gene expression of the meiotic genes $\operatorname{Rec} 8$ and $S c p 3$. In a previous study, it has been confirmed that exposure to a $20-\mu \mathrm{M}$ forskolin concentration can induce meiotic prophase progression in the organ culture of the fetal rabbit ovaries ${ }^{[23]}$. 

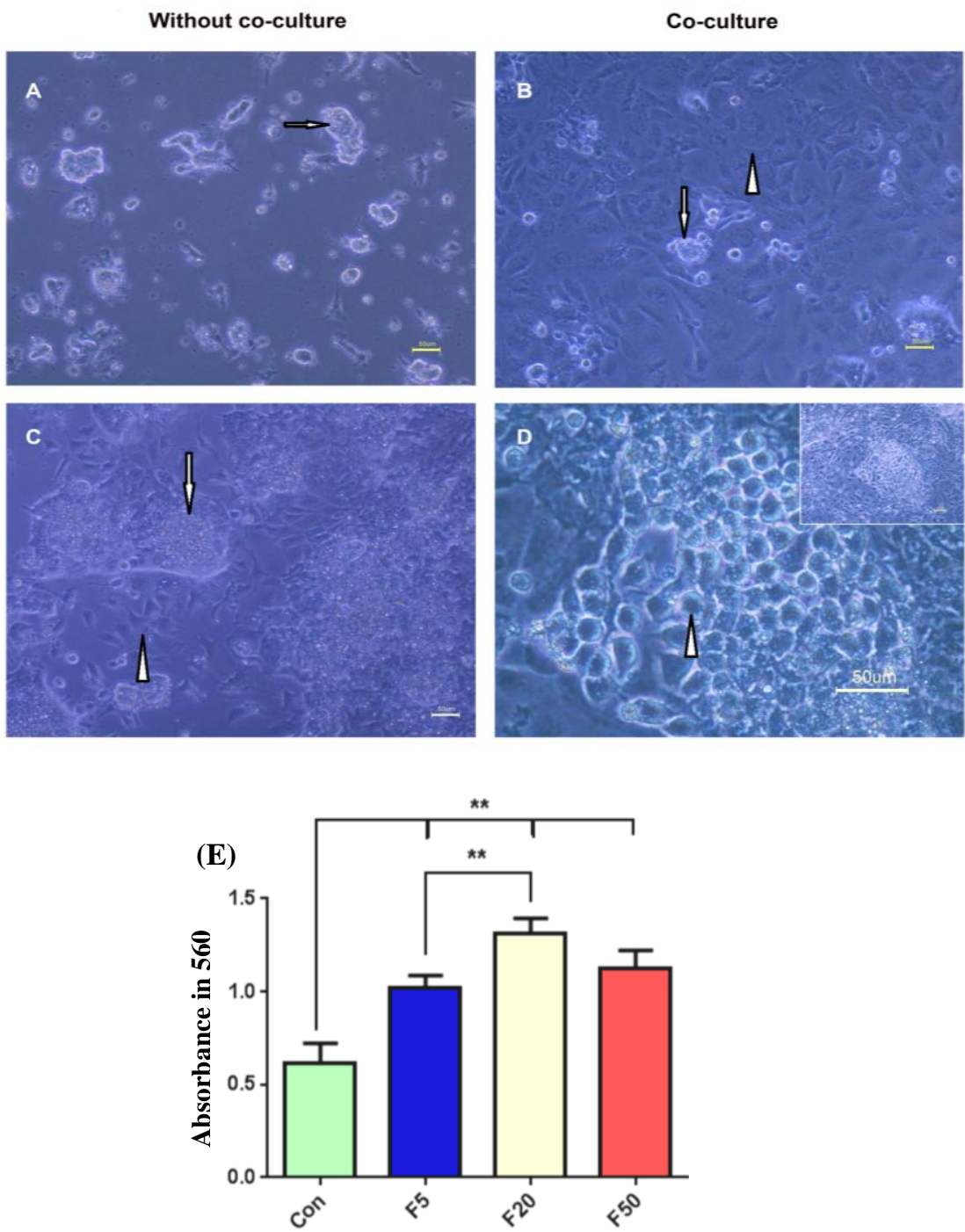

Fig. 4. Morphological assessment of differentiated cells after treatment in various concentrations of forskolin in the absence (A and C) or presence (B and D) of the GC co-culturing. The phase-contrast microscopy revealed that differentiated colonies (arrows) in day one were surrounded by (C) flat-shape cells (arrowhead) in the absence of the GCs in day three. The differentiated cells manifested as (D) round and large germ-like cells (arrowhead) around the colonies (arrow) when cultured on the granulosa feeder layer (B, arrowhead). Scale bars, $50 \mu \mathrm{m}$. (E) Cell viability assay in differentiated cells cultured in the presence of different concentrations of forskolin $(\mathrm{F})$. Data are presented as means $\pm \mathrm{SD}(\mathrm{n}=3) .{ }^{* *} p<0.01$; Con, control

Moreover, increased cAMP concentration from 15.5 to 17.5 days post coitum was actively involved in establishing the primordial follicle pool and inducing early meiosis in the mice ovaries ${ }^{[12]}$. Another study has reported that $20 \mu \mathrm{M}$ of forskolin concentration triggered meiosis in the germ cells derived from 11.5 days post coitum XY genital ridges cultured in vitro, as it led to the increased expression of synaptonemal complex proteins ${ }^{[15]}$. In contrast, increased cAMP levels caused a delay in meiosis II progression in mature and immature oocytes, while it was able to regulate the oocyte developmental competence ${ }^{[14,18,24]}$. Hence, in the present study, Rec8 and Scp3 gene expressions in EB-derived differentiated cells through forskolin treatment indicated meiosis entry.

In the absence or presence of GC feeder layer, Stra8 expression elevated only at concentration of $5 \mu \mathrm{M}$ of forskolin, and other concentrations had no effect on the expression of this gene. There is strong and extensive evidence indicating the increased expression of Stra8 induced by RA in the germ cells after entering the genital ridges ${ }^{[25,26]}$. The induction of meiosis was reported by the presence of RA in the serum (FBS) introduced to the medium ${ }^{[27]}$. It seems that the low concentration of forskolin in the possible presence of approximately $3.6 \times 10^{-8} \mathrm{M} \mathrm{RA}^{[28]}$ in the $10 \% \mathrm{FBS}$ 
supplemented medium was able to stimulate Stra8 expression as a pre-meiotic gene, whereas higher forskolin doses inhibited the expression of this RAresponsive gene. Interestingly, a previous study has indicated that BMP4 and RA treatment of cultured spermatogonia increases Stra8 expression in comparison with RA stimulation alone ${ }^{[29]}$. On the other hand, Stra 8 expression is inhibited by the expression of Cyp26b1, a member of the cytochrome p450 superfamily ${ }^{[27]}$, and in GCs, Cyp26b1 mRNA is expressed at all developmental stages ${ }^{[30]}$. The results of our study showed that forskolin had no effect on inducing Stra8 expression in the co-culturing method.

The presence of round cells around colonies, known as a germ cell-like population, was revealed only after co-cultivation with GCs. In line with our finding, other studies have suggested the role of newborn ovarian GCs in oocyte-like cell differentiation from ES cells ${ }^{[1,4]}$. In the mouse embryo, Saiti et al. ${ }^{[31]}$ could distinguish primordial germ cells from the adjacent somatic cells by their large oval or round shape in the size range of $10 \mu \mathrm{M}$ after gonad colonization, which was consistent with our observations. Besides, in our study, germ cell-specific markers, such as $M v h, G d f 9$, $S c p 3$, and $\operatorname{Rec} 8$ demonstrated increased expression at $20 \mu \mathrm{M}$ forskolin concentration after co-culturing with GCs, but not without co-culturing. Several studies have reported that GCs secrete various soluble factors into the culture medium and play a significant role in gametogenesis $^{[32-35]}$. GCs are the main sources of cAMP, purines/pyrimidines, metabolites, and amino acids for oocytes, and these substances are transferred through the gap junctions. These small regulatory molecules are essential for growth and maturation of germ cells and oocytes ${ }^{[36]}$. In this regard, paracrine interactions between germ cells and the neighboring somatic cells by kit ligand/stem cell factor have been found to critically function in both female and male germ cell development ${ }^{[37]}$. Thus, these observations can be attributed to cross talks between GCs and EBderived dissociated cells. Moreover, the results of other studies have indicated forskolin ability to enhance the production of estrogen, progesterone, and cAMP in the cultured GCs in a dose-dependent manner that serves as a non-hormonal stimulator of these cells ${ }^{[38,39]}$

To determine the effect of forskolin on cell viability, we cultured cells differentiated from ES cells in various concentrations of forskolin for $72 \mathrm{~h}$. Under these conditions, forskolin treatment was able to increase cell proliferation in a dose-dependent manner. The optimal concentration of forskolin to enhance proliferation was at $20 \mu \mathrm{M}$. Some studies have depicted that different concentrations of forskolin (especially $20 \mu \mathrm{M}$ ) could enhance cell proliferation. It is believed that forskolin-induced cAMP synthesis, as a potent mitogen, is a major factor for optimal germ cell growth $^{[10,40-42]}$, which is in contrast to others that declared treatment with forskolin resulted a decrease in cellular viability ${ }^{[43,44]}$.

In summary, our findings revealed that forskolinmediated stem cell differentiation is dependent on dose and the type of cell culture (with or without GC co-culture). According to the expression of germ cell specific markers, forskolin can induce germ-like cell differentiation directly and through co-cultured GCs indirectly. However, in co-culture method, which has been used as the most successful system for induction of germ cell differentiation in previous studies, $20 \mu \mathrm{M}$ of forskolin concentration is suitable, and higher concentrations are not required.

\section{ACKNOWLEDGEMENTS}

This study was extracted from the M.Sc. thesis by Amirhesam Keshavarz. This study was conducted at the laboratory for stem cell research in the Anatomy Department affiliated to Shiraz University of Medical Sciences, Shiraz, Iran. The project was assigned as grant number 94-9875 in the office of the Vice Chancellor of Research Affairs, Shiraz University of Medical Sciences. Hereby, the authors would like to present their most sincere thanks to Ms. Salmannezhad and Ms. Sani for their technical assistance. The authors wish to thank Mr. H. Argasi at the Research Consultation Center (RCC) at Shiraz University of Medical Sciences for his invaluable assistance in editing this manuscript.

CONFLICT OF INTEREST. None declared.

\section{REFERENCES}

1. Bahmanpour S, Zarei Fard N, Talaei-Khozani T, Hosseini A, Esmaeilpour T. Effect of BMP4 preceded by retinoic acid and co-culturing ovarian somatic cells on differentiation of mouse embryonic stem cells into oocyte-like cells. Development, growth and differentiation 2015; 57(5): 378-388.

2. West FD, Machacek DW, Boyd NL, Pandiyan K, Robbins KR, Stice SL. Enrichment and differentiation of human germ-like cells mediated by feeder cells and basic fibroblast growth factor signaling. Stem cells 2008; 26(11): 2768-2776.

3. Wan Q, Lu H, Wu LT, Liu X, Xiang JB. Retinoic acid can induce mouse embryonic stem cell R1/E to differentiate toward female germ cells while oleanolic acid can induce R1/E to differentiate toward both types 
of germ cells. Cell biology international 2014; 38(12): 1423-1429.

4. Qing T, Shi Y, Qin H, Ye X, Wei W, Liu H, Ding M, Deng $\mathrm{H}$. Induction of oocyte-like cells from mouse embryonic stem cells by co-culture with ovarian granulosa cells. Differentiation 2007; 75(10): 902-911.

5. Miryounesi M, Nayernia K, Dianatpour M, Mansouri F, Modarressi MH. Co-culture of mouse embryonic stem cells with sertoli cells promote in vitro generation of germ cells. Iranian journal of basic medical sciences 2013; 16(6): 779-783.

6. Zhou Q, Wang M, Yuan Y, Wang X, Fu R, Wan H, Xie M, Liu M, Guo X, Zheng Y, Feng G, Shi Q, Zhao XY, Sha J, Zhou Q. Complete meiosis from embryonic stem cell-derived germ cells in vitro. Cell stem cell 2016; 18(3): 330-340.

7. Park TS, Galic Z, Conway AE, Lindgren A, van Handel BJ, Magnusson M, Richter L, Teitell MA, Mikkola HK, Lowry WE, Plath K, Clark AT. Derivation of primordial germ cells from human embryonic and induced pluripotent stem cells is significantly improved by coculture with human fetal gonadal cells. Stem cells 2009; 27(4): 783-795.

8. Ohta H, Kurimoto K, Okamoto I, Nakamura T, Yabuta Y, Miyauchi H, Yamamoto T, Okuno Y, Hagiwara M, Shirane K, Sasaki H, Saitou M. In vitro expansion of mouse primordial germ cell-like cells recapitulates an epigenetic blank slate. The EMBO journal 2017; 36(13): 1888-1907.

9. Fimia GM, Sassone-Corsi P. Cyclic AMP signalling. Journal of cell science; 114(Pt 11): 1971-1972.

10. Farini D, Scaldaferri ML, Iona S, La Sala G, De Felici M. Growth factors sustain primordial germ cell survival, proliferation and entering into meiosis in the absence of somatic cells. Developmental biology 2005; 285(1): 4956.

11. Freeman G,Ridgway EB. The role of cAMP in oocyte maturation and the role of the germinal vesicle contents in mediating maturation and subsequent developmental events in hydrozoans. Roux's archives of developmental biology 1988; 197(4): 197-211.

12. Wang Y, Teng Z, Li G, Mu X, Wang Z, Feng L, Niu W, Huang K, Xiang X, Wang C, Zhang H, Xia G. Cyclic AMP in oocytes controls meiotic prophase I and primordial folliculogenesis in the perinatal mouse ovary. Development 2015; 142(2): 343-351.

13. Yi JH, Lefièvre L, Gagnon $\mathrm{C}$, Anctil M, Dubé F. Increase of cAMP upon release from prophase arrest in surf clam oocytes. Journal of cell science 2002; 115(Pt 2): $311-320$.

14. Bernal-Ulloa SM, Heinzmann J, Herrmann D, Hadeler KG, Aldag P, Winkler S, Pache D, Baulain U, LucasHahn A, Niemann H. Cyclic AMP affects oocyte maturation and embryo development in prepubertal and adult cattle. PLoS one 2016; 11(2): e0150264.

15. Yao HHC, Capel B. Disruption of testis cords by cyclopamine or forskolin reveals independent cellular pathways in testis organogenesis. Developmental biology 2002; 246(2): 356-365.

16. Sun MH, Zheng J, Xie FY, Shen W, Yin S, Ma JY.
Cumulus cells block oocyte meiotic resumption via gap junctions in cumulus oocyte complexes subjected to DNA double-strand breaks. PLoS one 2015; 10(11): e0143223.

17. Chen J, Chi MM, Moley KH, Downs SM. cAMP pulsing of denuded mouse oocytes increases meiotic resumption via activation of AMP-activated protein kinase. Reproduction 2009; 138(5): 759-770.

18. Shu YM, Zeng HT, Ren Z, Zhuang GL, Liang XY, Shen HW, Yao SZ, Ke PQ, Wang NN. Effects of cilostamide and forskolin on the meiotic resumption and embryonic development of immature human oocytes. Human reproduction 2008; 23(3): 504-513.

19. Nagy A, Rossant J, Nagy R, Abramow-Newerly W, Roder JC. Derivation of completely cell culture-derived mice from early-passage embryonic stem cells. Proceedings of the national academy of sciences USA 1993; 90(18): 8424-8428.

20. Sèdes L, Leclerc A, Moindjie H, Cate RL, Picard JY, Di di Clemente N, Jamin SP. Anti-Müllerian hormone recruits BMPR-IA in immature granulosa cells. PLoS one $2013 ; \mathbf{8}(11)$ : e81551.

21. Anderson RA, Fulton N, Cowan G, Coutts S, Saunders PT. Conserved and divergent patterns of expression of DAZL, VASA and OCT4 in the germ cells of the human fetal ovary and testis. BMC developmental biology 2007; 7(1): 136.

22. Otsuka F, McTavish KJ, Shimasaki S. Integral role of GDF-9 and BMP-15 in ovarian function. Molecular reproduction and development 2011; 78(1): 9-21.

23. Sasabe M, Terada T, Tsutsumi Y. A preliminary report on the effect of forskolin on the meiotic progress of germ cells into prophase I in fetal rabbit ovaries cultured in vitro. The journal of the faculty of applied biological science 1990; 29(2): 87-94.

24. Racowsky C. Effect of forskolin on maintenance of meiotic arrest and stimulation of cumulus expansion, progesterone and cyclic AMP production by pig oocyte - cumulus complexes. Journal of reproduction and fertility 1985; 74(1): 9-21.

25. Zhou Q, Nie R, Li Y, Friel P, Mitchell D, Hess RA, Small C, Griswold MD. Expression of stimulated by retinoic acid gene 8 (Stra8) in spermatogenic cells induced by retinoic acid: an in vivo study in vitamin Asufficient postnatal murine testes. Biology reproduction 2008; 79(1): 35-42.

26. Childs AJ, Cowan G, Kinnell HL, Anderson RA, Saunders PT. Retinoic acid signalling and the control of meiotic entry in the human fetal gonad. PLoS one 2011; 6(6): e20249.

27. Le Bouffant R, Guerquin MJ, Duquenne C, Frydman N, Coffigny H, Rouiller-Fabre V, Frydman R, Habert R, Livera G. Meiosis initiation in the human ovary requires intrinsic retinoic acid synthesis. Human reproduction 2010; 25(10): 2579-2590.

28. Marques-Mari AI, Lacham-Kaplan O, Medrano JV, Pellicer A, Simón C. Differentiation of germ cells and gametes from stem cells. Human reproduction update 2009; 15(3): 379-390.

29. Yang Y, Feng Y, Feng X, Liao S, Wang X, Gan H, 
Wang L, Lin X, Han C. BMP4 cooperates with retinoic acid to induce the expression of differentiation markers in cultured mouse spermatogonia. Stem cells international 2016; 2016: Article ID 9536192.

30. Kipp JL, Golebiowski A, Rodriguez G, Demczuk M, Kilen SM, Mayo KE. Gene expression profiling reveals Cyp26b1 to be an activin regulated gene involved in ovarian granulosa cell proliferation. Endocrinology 2011; 152(1): 303-312.

31. Saiti D, Lacham-Kaplan O. Mouse germ cell development in-vivo and in-vitro. Biomarker insights 2007; 2: 241-252.

32. Fabbri R, Porcu E, Marsella T, Primavera MR, Cecconi S, Nottola SA, Motta PM, Venturoli S, Flamigni C. Human embryo development and pregnancies in an homologous granulosa cell coculture system. Journal of assisted reproduction and genetics 2000; 17(1): 1-12.

33. Matzuk MM, Burns KH, Viveiros MM, Eppig JJ. Intercellular communication in the mammalian ovary: oocytes carry the conversation. Science 2002; 296(5576): 2178-2180.

34. Zolti M, Ben-Rafael Z, Meirom R, Shemesh M, Bider $\mathrm{D}$, Mashiach S, Apte RN. Cytokine involvement in oocytes and early embryos. Fertility and sterility 1991; 56(2): 265-272.

35. Shah SM, Saini N, Ashraf S, Singh MK, Manik RS, Singla SK, Palta P, Chauhan MS. Cumulus cellconditioned medium supports embryonic stem cell differentiation to germ cell-like cells. Reproduction, fertility and development 2017; 29(4): 679-693.

36. Gilchrist R, Ritter L, Armstrong D. Oocyte-somatic cell interactions during follicle development in mammals. Animal reproduction science 2004; 82: 431-446.

37. Thomas FH, Vanderhyden BC. Oocyte-granulosa cell interactions during mouse follicular development: regulation of kit ligand expression and its role in oocyte growth. Reproductive biology and endocrinology 2006; 4(1): 19.

38. Ranta T, Knecht M, Darbon JM, Baukal AJ, Catt KJ. Induction of granulosa cell differentiation by forskolin: stimulation of adenosine 3',5'-monophosphate production, progesterone synthesis, and luteinizing hormone receptor expression. Endocrinology 1984; 114(3): 845-850.

39. Welsh TH Jr, Jia XC, Hsueh AJ. Forskolin and phosphodiesterase inhibitors stimulate rat granulosa cell differentiation. Molecular and cellular endocrinology 1984; 37(1): 51-60.

40. Misra UK,Pizzo SV. Coordinate regulation of forskolininduced cellular proliferation in macrophages by protein kinase A/cAMP-response element-binding protein (CREB) and Epac1-Rap1 signaling: effects of silencing CREB gene expression on Akt activation. Journal of biological chemistry 2005; 280(46): 38276-38289.

41. De Felici M, Dolci S, Pesce M. Proliferation of mouse primordial germ cells in vitro: a key role for cAMP. Developmental biology 1993; 157(1): 277-280.

42. De Felici M, Klinger FG, Farini D, Scaldaferri ML, Iona S, Lobascio M. Establishment of oocyte population in the fetal ovary: primordial germ cell proliferation and oocyte programmed cell death. Reproductive biomedicine online 2005; 10(2): 182-191.

43. Liu L, Xie Y, Lou L. Cyclic AMP inhibition of proliferation of hepatocellular carcinoma cells is mediated by Akt. Cancer biology and therapy 2005; 4(11): 1240-1247.

44. Rodriguez G, Ross JA, Nagy ZS, Kirken RA. Forskolininducible cAMP pathway negatively regulates T-cell proliferation by uncoupling the interleukin-2 receptor complex. Journal of biological chemistry 2013; 288(10): 7137-7146. 